UDK $577.1: 61$

ISSN 1452-8258

J Med Biochem 39: 32-39, 2020

\title{
GLUCOSE METERS: WHAT'S THE LABORATORY REFERENCE GLUCOSE?
}

\section{GLUKOMETRI: ŠTA JE LABORATORIJSKI REFERENTNO ZA GLUKOZU?}

\author{
Mariarosa Carta ${ }^{1}$, Davide Giavarina ${ }^{1}$, Andreina Paternoster ${ }^{1}$, Graziella Bonetti ${ }^{2 *}$ \\ ${ }^{1}$ Clinical Laboratory, St. Bortolo Hospital, Vicenza, Italy \\ ${ }^{2}$ Central Clinical Chemistry Laboratory, Spedali Civili of Brescia, Brescia, Italy \\ * on behalf of the Italian joint SIBioC-SIPMeL Study Group on Diabetes Mellitus
}

\section{Summary}

Background: The accuracy of glucose meters is evaluated by comparing their results with those from a reference laboratory glucose analyser. The main scientific societies recommend the use of a prompt glycolysis inhibitor such as citrate for an accurate glucose determination. In the present preliminary study, we discuss the bias between capillary and plasma glucose measured concentrations, determined in two Italian clinical laboratories, using tubes containing an $\mathrm{NaF}$ and citrate mixture in liquid and granular form.

Methods: 139 volunteers in whom $75 \mathrm{~g}$ OGTT was requested were recruited. Basal capillary glucose was determined using Abbott FreeStyle Precision $\mathrm{Neo}$ in Brescia $(n=63)$, while clinical laboratory reference P-glucose was determined using tubes containing $\mathrm{NaF} / \mathrm{K}_{3}$ EDTA and liquid $\mathrm{NaF} / \mathrm{Na}$ EDTA/citrate. Basal capillary glucose was determined using a Roche Cobas Accu-Chek Inform II in Vicenza $(n=76)$, while P-glucose was determined using tubes containing $\mathrm{NaF} / \mathrm{K}_{2} \mathrm{Ox}$ and $\mathrm{NaF} / \mathrm{Na}_{2}$ EDTA/citrate in granulated form. Reference P-glucose was determined with a hexokinase method on Dimension Vista systems. Differences between capillary and reference P-glucose were evaluated according to ADA/ISO 15197:2013 specifications.

Results: $96.82 \%$ and $97.37 \%$ of capillary determinations were within specifications when liquid and granular citrate

Address for correspondence:

Graziella Bonetti

A.S.S.T. Spedali Civili of Brescia, Central Clinical Chemistry Laboratory

1 Piazzale Spedali Civili

25123 Brescia, Italy

e-mail: graziella.bonetti@asst-spedalicivili.it

\section{Kratak sadržaj}

Uvod: Tačnost glukometra se procenjuje poređenjem njihovih rezultata sa rezultatima dobijenim referentnim analizatorom za glukozu. Stručna zajednica preporučuje upotrebu brzog inhibitora glikolize kao što je citrat za precizno određivanje glukoze. U ovoj preliminarnoj studiji razmatrana su odstupanja između izmerenih koncentracija kapilarne glukoze i glukoze u plazmi, koje su obavljene u dve italijanske referentne laboratorije, primenom epruveta sa mešavinom $\mathrm{NaF}$ i citrata u tečnom i granularnom obliku. Metode: Odabrano je 139 dobrovoljaca i od njih zatraženo da urade OGTT test sa 75 g glukoze. Bazalna kapilarna glukoza je određena korišcenjem Abbott FreeStyle Precision Neo u Breši $(n=63)$, dok je laboratorijska referentna P-glukoza određivana korišćenjem $\mathrm{NaF} / \mathrm{K}_{3} \mathrm{EDTA}$ i tečnih $\mathrm{NaF} / \mathrm{Na}_{2} \mathrm{EDTA} /$ citrata koji sadrže epruvete. Bazalna kapilarna glukoza je određena korišćenjem Roche Cobas Accu-Chek Inform II u Vićenci $(n=76)$, dok je P-glukoza određena pomoću $\mathrm{NaF} / \mathrm{K}_{2} \mathrm{Ok}$ i $\mathrm{NaF} / \mathrm{Na}_{2}$ EDTA/citrata u granularnoj formi koja sadrži epruvete. Referentna $\mathrm{P}$ glukoza je određena metodom heksokinaze na Dimension Vista sistemima. Razlike između kapilarne i referentne Pglukoze su procenjene prema ADA/ISO 15197:2013 specifikacijama.

Rezultati: 96,82\% i 97,37\% kapilarnih određivanja bilo je u okviru specifikacija kada su korišćene epruvete sa tečnom i

List of abbreviations: ADA, American Diabetes Association; BGM, blood glucose meter; ISO, International Organization for Standardization; CLSI, Clinical and Laboratory Standard Institute; EDTA, ethylenediaminetetraacteic acid; FDA, US Food and Drug Administration; $\mathrm{K}_{2} \mathrm{Ox}$, Potassium Oxalate; IFCC, International Federation of Clinical Chemistry and Laboratory Medicine; GMECC, How should Glucose Meters be Evaluted in Critical Care; NACB, National Academy of Clinical Biochemistry; NaF, Sodium fluoride; OGTT, Oral Glucose Tolerance Test; POC, Point of Care; QC, Quality Control; SIBioC, Italian Society of Clinical Biochemistry; SID, Italian Society of Diabetology; SIPMeL, Italian Society of Clinical Pathology and Laboratory Medicine; WG, Working Group. 
mixture tubes were used, respectively. Conversely, only $73.02 \%$ and $80.26 \%$ of determinations were within criteria using $\mathrm{NaF}$.

Conclusions: It's important to know what is the laboratory reference glucose in evaluating glucose meters' accuracy. The evaluation of glucometers' accuracy with respect to a reference laboratory may be wrong if tubes containing only $\mathrm{NaF}$ are used due to in vitro glycolysis. Only tubes containing citrate mixture permit the correct evaluation of glucose meters' accuracy.

Keywords: blood glucose, blood glucose meters, citrate buffer, sodium fluoride

\section{Introduction}

The measurement of glucose represents a cornerstone in the diagnosis of carbohydrate metabolism disorders and in the care of all people with diabetes (1). Point of Care (POC) glucose meters (from this point onwards, referred to only as glucose meters) are commonly used to quickly obtain glucose determinations at hospital and home. The American Diabetes Association (ADA) recommends their use for selfmonitoring at home or in clinical settings (2). Glucose meters are easy to use and cost-effective and have also become the method of choice in many laboratories in the context of the evaluation of basal glucose determination in the Oral Glucose Tolerance Test (OGTT). There is some debate over what constitutes good technical accuracy when comparing glucose meters with a laboratory method. Multiple performance goals have been proposed for portable glucose meters. These targets vary widely. The ADA specifies the criteria for total error of glucose meters: At least $95 \%$ of a glucose meter's results have to be within $< \pm 0.8 \mathrm{mmol} / \mathrm{L}$ at glucose concentrations $<5.6 \mathrm{mmol} / \mathrm{L}$ and within $\pm 15 \%$ at glucose concentrations $\geq 5.6 \mathrm{mmol} / \mathrm{L}$. The international standard ISO 15197:2013 specifies the same criteria for accuracy of glucose meters but introduces a second trueness criterion relating to the consensus error grid that assigns pairs of glucose meters' results and a corresponding reference value to a clinical risk zone: at least $99 \%$ of results have to be within the consensus error zones $A$ and $B(4)$. The more stringent CLSI POCT12-A3 recommendations are that, for $95 \%$ of the samples, the difference between glucose meter and laboratory measurements of glucose have to be (a) $<12.5 \%$ when the laboratory glucose value is $>5.6 \mathrm{mmol} / \mathrm{L}$ and $(b)<0.7 \mathrm{mmol} / \mathrm{L}$ of the laboratory glucose value when the glucose concentration is $\leq 5.6 \mathrm{mmol} / \mathrm{L}$ (5). The Food and Drug Administration (FDA) 2016 criteria state that $95 \%$ of glucose values must be within $15 \%$ of reference and $99 \%$ of glucose values must be within $20 \%$ of reference (6).

In any case, glucose meters' accuracy is based on a comparison of POC and laboratory reference glucose results. Moreover, for quality assurance, the ADA recommends a periodic comparison of the granularnom mešavinom citrata. Nasuprot tome, samo $73,02 \%$ i $80,26 \%$ određivanja je bilo u okviru kriterijuma pomocu $\mathrm{NaF}$.

Zaključak: Važno je znati šta je laboratorijska referentna glukoza u proceni tačnosti glukometra. Ispitivanje preciznosti glukometra u odnosu na referentu laboratoriju može biti pogrešno ako se koriste epruvete koje sadrže samo $\mathrm{NaF}$ zbog in vitro glikolize. Samo epruvete koje sadrže citratnu mešavinu omogucavaju ispravnu procenu tačnosti glukometra.

Ključne reči: glukoza u krvi, glukometri, citratni pufer, natrijum fluorid

results from glucose meters with those from referenced laboratories (3). In-vitro instability of whole blood glucose can introduce an important bias in the accuracy assessment of glucose meters. For this reason, all steps in the analytical and pre-analytical processes require careful attention $(7,8)$. In vitro glycolysis, which results in the breakdown of glucose, is the principal source of uncertainty in glucose determinations. An average reduction of glucose concentration of 5-7\%/hour can occur, especially when high leukocyte blood counts and high temperatures are present (9). For accurate glucose determinations, tubes containing anti-glycolytic agents are used (10). The most commonly used anti-glycolytic agent, sodium fluoride $(\mathrm{NaF})$, acts inhibiting enolase activity (11). $\mathrm{NaF}$ is a long-term glucose stabilizer, but it does not prevent a drop during the first hours after blood drawing (12). In most Italian clinical laboratories, glucose is usually determined in tubes containing sodium fluoride ( $\mathrm{NaF}$ ) (13). However, to prevent in vitro glycolysis, the Italian working group on diabetes of the Italian Society of Clinical Biochemistry (SIBioC) and the Italian Society of Clinical Pathology and Laboratory Medicine (SIPMeL), together with representatives of the Italian Society of Diabetology (SID), the American Diabetes Association (ADA) and the National Academy of Clinical Biochemistry (NACB), recommend the collection of blood into tubes containing a rapid glycolysis inhibitor, i.e., a citrate buffer, in a granular or liquid form that acts immediately inhibiting hexokinase, the first enzyme of the glycolytic pathway, instead of using $\mathrm{NaF}$ alone $(3,14)$.

Since the instability of glucose in blood can introduce important bias in the assessment of glucose meters, we have planned a preliminary study to quantify the bias of glucose measured by two different glucose meters (i.e., Abbott FreeStyle Precision Neo and Roche Cobas Accu-Chek Inform II) based on ADA and ISO 15197:2013 requirements with respect to reference glucose measured in laboratories using $\mathrm{NaF}$ and the two universally commercially available recommended citrate-containing tubes (GlucoEXACT from Sarstedt and FC-Mix from Greiner Bio-One) (10, 12, 16). 


\section{Materials and Methods}

The study was conducted at Spedali Civili Central Clinical Chemistry Laboratory (Brescia, Italy) and at the Laboratory of St. Bortolo Hospital (Vicenza, Italy) in summer 2018. One hundred thirtynine volunteers (13 men, 126 women), median age 35 years (interquartile range (IQR): 31-48), in whom a $75 \mathrm{~g}$ OGTT was requested, were recruited.

Basal capillary whole blood glucose was determined using Abbott FreeStyle Precision $\mathrm{Neo}$ in Brescia and a Roche Cobas Accu-Chek Inform II in Vicenza. All capillary whole blood glucose measurements were carried out by the same trained nurses, and all venepunctures were performed in each study by a single experienced phlebotomist to minimize venepuncture bias.

To evaluate the glucose meters' performance, internal quality control (QC) materials (high and low levels) were tested daily according to the manufacturers' instructions.

Reference plasma glucose was determined in the tube containing NaF-K 3 EDTA, $2.7 \mathrm{~mL}$ draw (Ref. 04.1918 from Sarstedt Verona, Italy), and the tube containing $\mathrm{Na}_{2}$ EDTA, $\mathrm{NaF}$, citric acid, and Na-citrate in a liquid form, GlucoEXACT, $3.1 \mathrm{~mL}$ draw (Ref. 04.1945.001 from Sarstedt Verona, Italy), in Brescia.

Reference plasma glucose was determined in the tube containing $\mathrm{NaF}-\mathrm{K}_{2}$ oxalate $\left(\mathrm{NaF} / \mathrm{K}_{2} \mathrm{Ox}\right), 2$ $\mathrm{mL}$ draw (Ref. 454514 from Vacutest Kima, Arzegrande, Italy), and the tube containing $\mathrm{Na}$,EDTA, NaF, citric acid, and $\mathrm{Na}$-citrate in a granular form, FC-MIX, 2 mL draw (Ref. 454511 from Greiner Bio-One, Cassina de Pecchi, Italy), in Vicenza.

Plasma glucose concentration measurements were performed by Dimension Vista 1500 analyzers (Siemens Healtheers, Milan, Italy) using a hexokinase method (within-laboratory $\mathrm{CV}=2.1 \%$ at Brescia and $2.8 \%$ at Vicenza laboratory) upon arrival at the clinical laboratory, between 3 and 4 hours after blood drawing. QC was performed according to the laboratory specifications.

Glucose concentrations measured in GlucoEXACT tubes containing a liquid mixture of $\mathrm{NaF}$, $\mathrm{Na}_{2}$ EDTA, and citrate were multiplied by 1.16 as recommended by the manufacturer in order to overcome the sample's dilution by liquid addictive.

\section{Ethics}

The study was conducted according to the principles of the revised Helsinki Declaration, adopted in 2013 (Fortaleza, Brazil), and written informed consent was obtained from all participants.

\section{Statistics}

Normal distributions for all the datasets were evaluated by using the Kolmogorov-Smirnov test. Since normal distribution was not confirmed, the Wilcoxon test for paired samples was used to compare reference laboratory glucose in tubes containing $\mathrm{NaF}$ and citrate to those measured by glucose meters. The biases between capillary glucose and venous reference glucose in $\mathrm{NaF}$ and citrate mixture tubes were calculated as $B=$ ((Glu Glucose meter $)$ Glu Reference) $\times 100)-100$. The acceptance criteria were defined according to ADA and ISO 15197:2013 (total error for $95 \%$ of samples to $15 \%$ at glucose concentrations $\geq 5.6 \mathrm{mmol} / \mathrm{L}$ and to $<0.8$ $\mathrm{mmol} / \mathrm{L}$ at glucose concentrations $<5.6 \mathrm{mmol} / \mathrm{L}$ and difference plots created. The statistical analysis was performed with MedCalc software, version 18.10.2 (Ostend, Belgium). Values of $p<0.05$ were considered statistically significant.

\section{Results}

The median glucose concentration in the whole blood capillary sample using the Abbott FreeStyle Precision Neo glucose meter $(n=63)$ was 5.11 (IQR:4.68-5.50-99.0) $\mathrm{mmol} / \mathrm{L}$, and reference venous plasma glucose using tubes containing $\mathrm{NaF} / \mathrm{K}_{3}$ EDTA was 4.46 (IQR:4.13-4.95) $\mathrm{mmol} / \mathrm{L}$ $(p<0.0001)$, while that obtained using a liquid form of $\mathrm{NaF} / \mathrm{Na}_{2} \mathrm{EDTA} /$ citrate (i.e., GlucoEXACT) was 5.00 (IQR: 4.60-5.48-98.6) mmol/L ( $p=0.0059)$.

The median glucose concentration in the whole blood capillary sample using the Roche Cobas AccuChek Inform II glucose meter $(n=76)$ was 5.22 (IQR: 4.78-5.83) $\mathrm{mmol} / \mathrm{L}$, and reference venous plasma glucose using tubes containing $\mathrm{NaF} / \mathrm{K}_{2} \mathrm{Ox}$ was 4.64 (IQR: 4.11-5.17) $\mathrm{mmol} / \mathrm{L}(p<0.0001)$, while that obtained using a granular form of $\mathrm{NaF} / \mathrm{Na}_{2}$ EDTA/citrate (i.e., FC-Mix) was 4.92 (IQR: 4.39-5.64) $\mathrm{mmol} / \mathrm{L}(\mathrm{p}<0.0001)$.

The difference plots illustrating the comparisons of glucose results from the whole blood capillary sample measured with the Abbott FreeStyle Precision Neo and the Roche Cobas Accu-Chek Inform II and the reference plasma glucose measured in tubes containing $\mathrm{NaF}$ and $\mathrm{NaF} / \mathrm{Na} 2 \mathrm{EDTA} /$ citrate in liquid and granular form are presented in Figures 1 and 2. Only $73.02 \%$ and $80.26 \%$ of capillary glucose determinations were within ADA - ISO 15197:2013 criteria when $\mathrm{NaF} / \mathrm{K}_{3} \mathrm{EDTA}$ and $\mathrm{NaF} / \mathrm{K}_{2} \mathrm{Ox}$ were used. Conversely, $96.82 \%$ and $97.37 \%$ of capillary glucose determinations were within ADA-ISO 15197:2013 criteria when liquid and granular citrate mixture tubes were used, respectively.

The correlation between capillary whole blood glucose using both the FreeStyle Precision Neo and the Roche Cobas Accu-Chek Inform II with respect to 

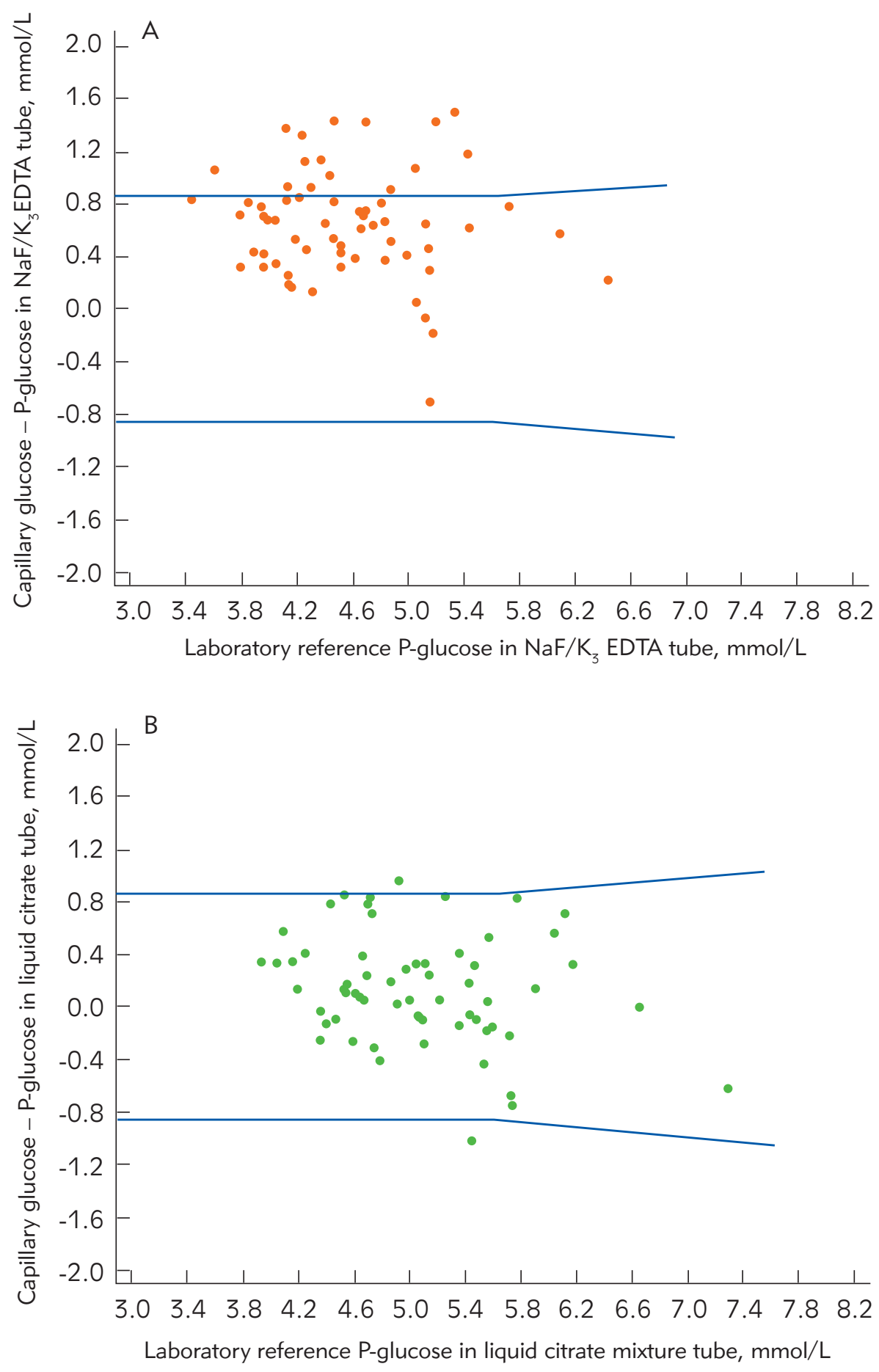

Figure 1 Difference plots of capillary glucose and laboratory venous plasma reference glucose in (A) NaF/K ${ }_{3} E D T A$ (NaF) tubes and (B) $\mathrm{NaF} / \mathrm{Na}_{2}$ EDTA/citrate tubes in a liquid form (GlucoEXACT). Blue lines indicate ADA and ISO 15197:2013 accuracy limits.

the plasma glucose concentration using hexokinase methods on Dimension Vista 1500 were $r=0.80$ when $\mathrm{NaF}$ and citrate liquid mixture (Table I) were used, respectively.
The correlation between capillary whole blood glucose on the Roche Cobas Accu-Chek Inform II and plasma glucose concentration were $r=0.94$ and $\mathrm{r}=0.92$ when $\mathrm{NaF}$ and citrate granular mixture (Table I) were used, respectively. 

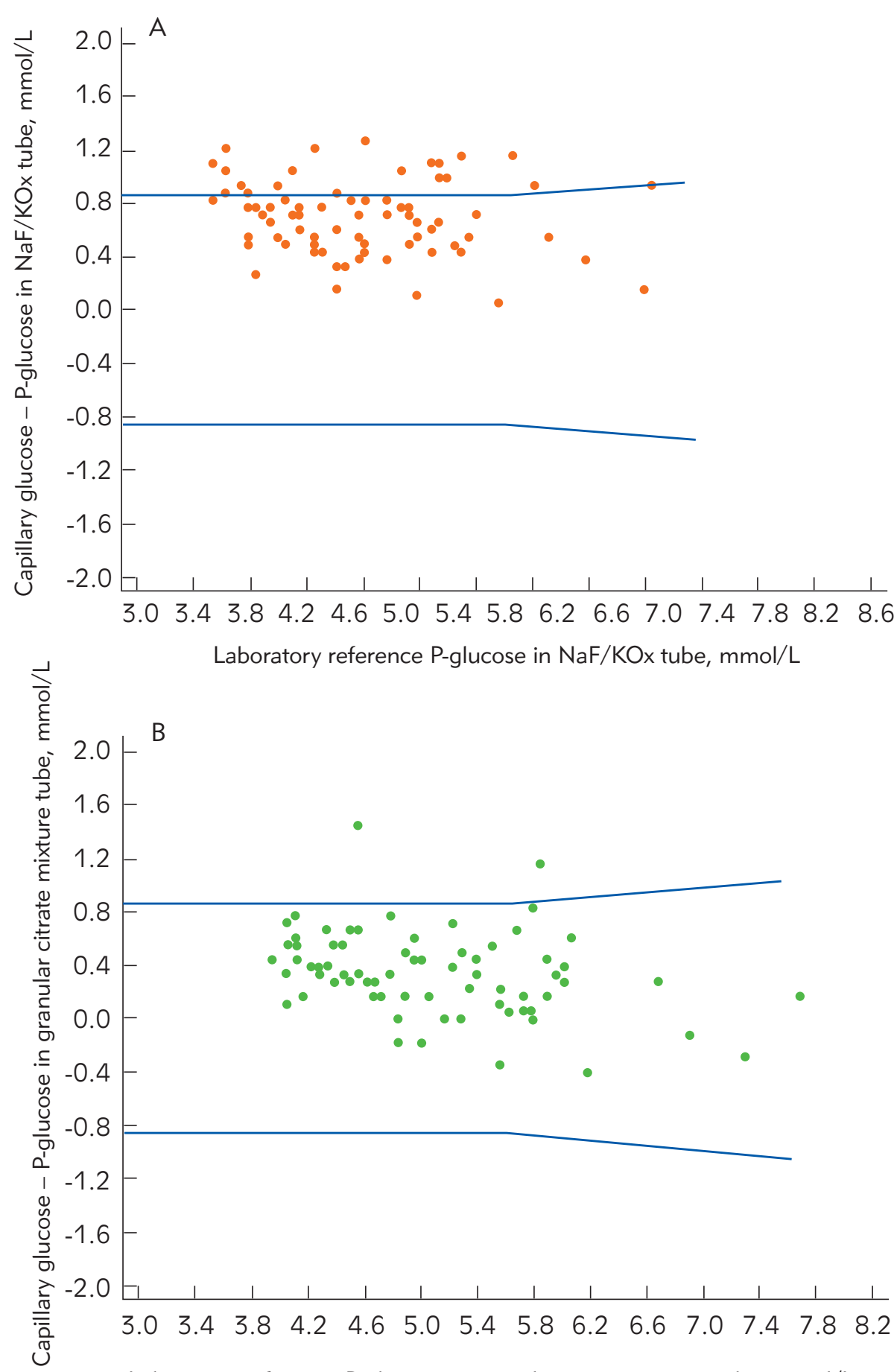

Laboratory reference P-glucose in granular citrate mixture tube, $\mathrm{mmol} / \mathrm{L}$

Figure 2 Difference plots of capillary glucose and venous plasma laboratory reference glucose in $(A) N a F / K_{2} \mathrm{Ox}$ tubes and $(B)$ $\mathrm{NaF} / \mathrm{Na}_{2} \mathrm{EDTA} /$ citrate tubes in a granular form (FC-Mix). Blue lines indicate ADA and ISO 15198:2013 accuracy limits.

\section{Discussion}

Glucose meters are often used for a fast evaluation of glucose concentrations in the hospital and at home. Many studies and reviews have evaluated glucose meters' technical trueness (17). Trueness is defined as the closeness of agreement between a test result and the true value of that analyte. An important but often neglected aspect that can affect POC system trueness results is the measurement procedure used (5). 
Table I Least square regression equations comparing capillary glucose in two different glucometers and plasma glucose in the tubes evaluated.

\begin{tabular}{|c|c|c|c|c|c|c|c|}
\hline$x$ & y & $\mathrm{N}$ & $\begin{array}{l}\text { Regression } \\
\text { equation }\end{array}$ & Slope 95\% Cl & Intercept $95 \% \mathrm{Cl}$ & $r$ & $\mathrm{~S}_{y / x}$ \\
\hline P-glucoseNaF/K ${ }_{3}$ EDTA & \multirow{2}{*}{$\begin{array}{c}\text { Capillary } \\
\text { glucose } \\
\text { (Abbott } \\
\text { FreeStyle Neo) }\end{array}$} & \multirow[b]{2}{*}{63} & $y=0.9204 x+1.0164$ & $0.7411-1.0997$ & $0.1924-1.8404$ & 0.796 & 0.4148 \\
\hline $\begin{array}{l}\text { P-glucose } \\
\text { Citrate mixture } \\
\text { (liquid - GlucoEXACT)) }\end{array}$ & & & $y=0.8349 x+0.9853$ & $0.6738-0.9960$ & $0.1631-1.8076$ & 0.796 & 0.4123 \\
\hline P-glucose $\mathrm{NaF} / \mathrm{K}_{2} \mathrm{Ox}$ & \multirow{2}{*}{\begin{tabular}{|c|} 
Capillary \\
glucose \\
(Roche Cobas \\
Accu-chek \\
Inform II)
\end{tabular}} & \multirow[b]{2}{*}{76} & $y=0.9429 x+0.9681$ & $0.8580-1.0278$ & $0.5647-1.3715$ & 0.932 & 0.2754 \\
\hline $\begin{array}{l}\text { P-glucose } \\
\text { Citrate mixture } \\
\text { (granular-Fc-MIX) }\end{array}$ & & & $y=0.8721 x+0.9825$ & $0.7872-0.9569$ & $0.5481-1.4170$ & 0.922 & 0.2944 \\
\hline
\end{tabular}

In fact, during transport to the laboratory to compare results with laboratory methods, glucose concentrations have a tendency to decrease due to in-vitro glycolysis. Delay in transportation can lead to biases between glucose meters and reference laboratory methods (18). A study from Salacinski and colleagues (19) suggested that the glucose meter provided poor-validity and-reliability results compared to the results provided by the reference laboratory analyser using lithium-heparin plasma samples. They indicated that portable glucose meters should be used for patient management but not for diagnosis, treatment, or research purposes (19). Fluoride-containing tubes are often used to reduce glycolysis, especially when accurate results are required, but it is known that the inhibitory effect of fluoride upon glycolysis can take to 2-3 h, with a consequent lowering of the glucose concentration in the first hours (20).

In a recent study, Blaurock and colleagues (21) evaluated the impact of glucose measuring systems on diagnosis rates of diabetes mellitus using POCT and core laboratory glucose methods. In the study limitations section, they reported that the effect of glycolysis could not be completely excluded because $\mathrm{NaF}$ was used (21). Already in 1996, the FDA suggested that fluoride should not be used as a preservative for venous specimens when using glucose meters (22). Hung et al. (22), using stored samples to evaluate glucose meters' accuracy with respect to their laboratory method, called this recommendation into question. However, in their letter, they did not describe how much time had passed between the sampling and the centrifugation of the $\mathrm{NaF}$ sample (22). Recently, IFCC Working Group WG-GMECC wrote a document on the clinical practice of using glucose meters and the requirements they must fulfil in order to be used in critical care, which emphasizes that anticoagulant preservatives such as $\mathrm{NaF}$-oxalate are not completely effective in inhibiting glycolysis and that the addition of citrate is the most effective (23). Our study is a preliminary one on the evaluation of the bias of two different glucose meters (i.e.,
Abbott FreeStyle Precision Neo and Roche Cobas Accu-Chek Inform II) in referencing venous plasma glucose using the new recommended citrate-containing tubes. In our study, capillary glucose concentrations obtained from glucose meters and venous plasma reference glucose determined by laboratory instruments using $\mathrm{NaF}$ and citrate tubes were evaluated as in typical scenarios experienced in patient care. The novelty of our study is that is the first to compare capillary whole blood glucose to reference plasma glucose using the two universally available tubes containing citrate in a liquid and granular form together with the old NaF-containing tubes $(10,16)$. Significant biases in glucose concentrations were observed between glucose meters and reference plasma glucose when different plasma tubes were used. Our data suggest that for an efficient comparison of glucose measured by glucose meter systems with the reference laboratory measurements, only plasma samples containing an acidified citrate mixture should be used in reference laboratories. NaF plasma tubes need to be abandoned because they exert biases exceeding analytical goals for bias according to ADA and ISO 15197:2013. Maintaining the use of $\mathrm{NaF}$ as a comparison system can cause incorrect evaluations of the quality of the glucose meters used. Previously, only van den Berg and colleagues' (24) study had considered citrate-containing tubes in POC evaluation. That study was about the screening of gestational diabetes mellitus. The glucose concentration determined by routine laboratory analysis using lithium-heparin tubes was well correlated with POC analysis but was lower at both T0 and T120 (24). The bias was lower if lithium-heparin tubes were centrifuged immediately. If citrate-containing tubes were used, the glucose concentrations determined within 60 minutes strongly correlated at both 0 and 120 minutes of OGTT.

Because the FDA suggests that fluoride should not be used as a preservative for venous specimens when using glucose meters, we could hypothesize that samples with an acidified mixture in liquid and granular form could be used as an efficient alternative. 
In this real-life study, there are some limitations. A limited number of participants were recruited, and plasma and capillary glucose measurements were made as single determinations and not in duplicate, as stated in the CLSI EP09c document (25). Because capillary glucose determinations are part of the basal evaluation of OGTT, only low and medium glucose concentrations were available, so an assessment of higher glucose concentrations is still required. Additional glucose meters need to be investigated since only two devices were considered in the present study.

Eventually, tight control of the pre-analytical procedures is needed, even using POC devices, as stated by the Working Group for the Preanalytical Phase of the European Federation for Clinical Chemistry and Laboratory Medicine (26).

\section{References}

1. American Diabetes Association. Standards of Medical Care. Classification and Diagnosis of Diabetes. Diabetes Care 2018;41 (Suppl 1): S13-S28.

2. American Diabetes Association: Self-monitoring of blood glucose (Consensus Statement). Diabetes Care 1996; 19: 62S-66S.

3. Sacks DB, Arnold M, Bakris GL, Bruns DE, Horvath AR, Kirkman MS, Lernmark $A$, et al. Guidelines and Recommendations for Laboratory Analysis in the Diagnosis and Management of Diabetes Mellitus. Clin Chem 2011; 57(6): e1-e47.

4. International Organization for Standardization. In vitro diagnostic test systems-requirements for blood-glucose monitoring systems for self-testing in managing diabetes mellitus. ISO 15197: 2013.

5. Clinical and Laboratory Standard Institute. Point-of-Care Blood Glucose Testing in Acute and Chronic Care Facilities; Approved Guideline - Third Edition. CLSI document POCT12-A3. Wayne, PA: Clinical and Laboratory Standards Institute; 2013.

6. US Food and Drug Administartion. Self-Monitoring Blood Glucose Test Systems for Over-the-Counter Use. Guidance for Industry and Food and Drug Administration Staff. Document issued on October 11, 2016. Available at: https://www.fda.gov/downloads/ucm 380327.pdf (accessed November 9th 2018).

7. Pasqualetti S, Braga F, Panteghini M. Pre-analytical and analytical aspects affecting clinical reliability of plasma glucose results. Clinical Biochemistry 2017; 50(10-11): 587-94.

8. Bailey TS, Klaff $\sqcup$, Wallace JF, Greene C, Pardo S, Harrison B, et al. Fundamental importance of reference glucose analyzer accuracy for evaluating the performance of blood glucose monitoring systems (BGMSs). J Diabetes Sci Technol 2016; 10(4): 872-5.

\section{Conclusions}

We have found that comparison of POC glucose analysis versus reference laboratory analysis may be wrong if tubes containing only $\mathrm{NaF}$ are used due to in vitro glycolysis. Furthermore, we have shown that the use of the new tubes with the acidified mixture, in either granular or liquid form, can be adequate for screening subjects who undergo an OGTT in order to correctly compare results to the reference laboratory plasma glucose, as well as for an accurate evaluation of glucose meters according to ADA and ISO 15197:2013 standards.

\section{Conflict of interest statement}

The authors stated that they have no conflicts of interest regarding the publication of this article.

9. Chan A, Swaminathan R, Cockram C. Effectiveness of sodium fluoride as a preservative of glucose in blood. Clin Chem 1989; 35(2): 315-17.

10. Cancelli V, Coccoli G, Piccinelli G, Brugnoni D, Caimi L, Carta M. Which sample tube should be used for routine glucose determination? Prim Care Diabetes. 2016 Jun; 10(3): 227-32. doi: 10.1016/j.pcd.2015.11.003. Epub 2015 Dec 4

11. Qin J, Chai G, Brewer JM, Lovelace LL, Lebioda L. Fluoride inhibition of enolase: crystal structure and thermodynamics. Biochemistry. 2006; 45(3): 793-800.

12. Bonetti G, Carta M, Montagnana M, Lo Cascio C, Bonfigli AR, Mosca A, et al. Effectiveness of citrate buffer-fluoride mixture in Terumo tubes as an inhibitor of in vitro glycolysis. Biochem Med 2016; 26(1): 68-76.

13. Giavarina D, Lippi G. A survey on sample matrix and preanalytical management in clinical laboratories. Biochim Clin 2017; 41: 142-7.

14. Bonetti G, Carta M, Lapolla A, Miccoli R, Testa R, Mosca A. on behalf of the SIBioC-SIPMeL working group on Diabetes. Correct determination of glycemia in the diagnosis and management of diabetes: recommendations for the optimization of the pre-analytical phase. Nutr Metab Cardiovasc Dis. 2019; 29 (1): 1-3. https://doi. org/10.1016/j.numecd.2018.09.013.

15. D'Orazio P, Burnett RW, Fogh-Andersen N, Jacobs E, Kuwa K, Külpmann WR, et al.; IFCC-SD-WG-SEPOCT. Approved IFCC recommendation on reporting results for blood glucose: International Federation of Clinical Chemistry and Laboratory Medicine Scientific Division, Working Group on Selective Electrodes and Point-of-Care Testing (IFCC-SD-WG-SEPOCT). Clin Chem Lab Med. 2006; 44(12): 1486-90.

16. Bonetti G, Carta M. The new Greiner FC-Mix tubes equal the old Terumo ones and are useful as glucose stabilizer after prolonged storage of samples. Biochem Med 
(Zagreb). 2017 Oct 15; 27(3): 030901. doi: 10.11613 /BM.2017.030901. Epub 2017 Aug 28.

17. Milinković N, Ignjatović S, Šumarac Z, Majkić-Singh N. Uncertainty of measurement in laboratory medicine. J Med Biochem 2018; 37: 279-88.

18. Arslan DF, Karakoyun I, Basok IB, Aksit ZM, Celik E, Dogan K, Duman C. The effects of education and training given to phlebotomists for reducing preanalytical errors. J Med Biochem 2018; 37: 172-80.

19. Salacinski AJ, Alford M, BS2, Drevets K, Hart S, Hunt BE. Validity and Reliability of a Glucose Meter Against Industry Reference Standards. Journal of Diabetes Science and Technology 2014; 8(1): 95-9.

20. Gambino R. Sodium fluoride: an ineffective inhibitor of glycolysis. Ann Clin Biochem 2013; 50(Pt 1): 3-5.

21. Blaurock MG, Kallner A, Menzel S, Masuch A, Nauck M, Petersmann A. Impact of Glucose Measuring Systems and Sample Type on Diagnosis Rates of Diabetes Mellitus. Diabetes Ther 2018; 9(5): 2029-41.

22. Hung YL, Cyue HH, Yi RL, Mao SI, Jung NW. Effect of Fluoride-Containing Tubes on Accuracy of Glucometers. Diabetes Care 2007; 31(5): e33.
23. IFCC Working Group GMECC. How should glucose meters be evaluated for critical care. Available at: http://www.ifcc.org/media/47721 (accessed November 9th 2018)

24. Van den Berg SAA, de Groot MJM, Salden LPW, Draad PJGJ, Dijkstra IM, Lunshof S, et al. Pregnancy diabetes: A comparison of diagnostic protocols based on point-ofcare, routine and optimized laboratory conditions. Scientific Reports | 5:16302 | DOI: 10.1038/ srep16302.

25. Clinical and Laboratory Standard Institute. Measurement Procedure Comparison and Bias Estimation Using Patient Samples. 3rd ed. CLSI guideline EP09c. Wayne, PA: Clinical and Laboratory Standards Institute; 2018.

26. Lippi G, Baird GS, Banfi G, Bölenius K, Cadamuro J, Church $S$, et al., on behalf of the European Federation for Clinical Chemistry and Laboratory Medicine (EFLM) Working Group for Preanalytical Phase (WG-PRE). Improving quality in the preanalytical phase through innovation, on behalf of the European Federation for Clinical Chemistry and Laboratory Medicine (EFLM) Working Group for Preanalytical Phase (WG-PRE). Clin Chem Lab Med 2017; 55(4): 489-50. 